\title{
Mice behavioural models with pooled data analysis of Gelsemium studies and new findings about Ignatia and Aconitum
}

\author{
Paolo Bellavite, Paolo Magnani, Marta Marzotto, Mirko Cristofoletti, \\ Mariaelisabetta Zanolin, Anita Conforti \\ University of Verona (I), Italy
}

\begin{abstract}
Objective: We investigated the effects of three different homeopathic medicines in several dilutions/dynamizations on mice, using validated models which explore anxiety-like and emotional symptoms. Two complete series of investigations were performed in order to assess the activity of Gelsemium sempervirens; furthermore, we investigated Ignatia amara and Aconitum napellus in the same model systems.

Methods: Mice of CD1 strain were randomized in different cages (minimum 8 mice per treated group in each experiment) and treatment solutions were coded in such a way that all protocols were carried out fully in blind. The indicated compounds at various centesimal dilutions/dynamizations, a control solution (the solvent vehicle of drugs, which was succussed before administration) or the reference drugs diazepam (1 $\mathrm{mg} / \mathrm{kg}$ body weight) or buspirone ( $5 \mathrm{mg} / \mathrm{kg}$ body weight) diluted in the same succussed solvent were delivered intraperitoneally $(0.3 \mathrm{ml} / \mathrm{mice})$ for 9 days. A series of changes of animal behavior were assessed by the LightDark (LD) choice test and the Open-Field (OF) exploration test. Two series of studies with little technical differences, exploiting a total of 14 separate experiments, were carried out with Gelsemium, five complete experiments with Ignatia and four complete experiments with Aconitum.
\end{abstract}

Results: In both series of experiments Gelsemium showed anxiolytic-like effects using both OF test (permanence and movement in centre area of field) and LD test (time spent in lit area and number of lightdark transitions). However, due to high variability of animal responses and possibly to some minor differences in protocols, those effects reached the threshold of statistical significance only in OF in the first series and only in LD in the second series. Cumulative analysis of the two series demonstrated a highly significant $(\mathrm{p}<0.0001)$ effect of Gelsemium $5 \mathrm{CH}, 7 \mathrm{CH}$, and $30 \mathrm{CH}$ in $\mathrm{OF}$ parameters and of Gelsemium $5 \mathrm{CH}, 9 \mathrm{CH}$, and $30 \mathrm{CH}$ in LD parameters. In OF the effect of Gelsemium was evident at variance with the effect of the standard drugs diazepam and buspirone, suggesting an increase in exploratory behavior and a decrease in thigmotaxis or in neophobia, instead of a pure anxiolytic effect; in LD test the effects of Gelsemium were in the same direction as those of benzodiazepines. Ignatia showed statistically significant effects only in the LD test parameters (peak at $9 \mathrm{CH}$ dilution/dynamization), while Aconitum anxiolytic-like effects were evident only in one experiment where the basal anxiety level of mice was very high. In addition, we observed a tendency of Ignatia to decrease the number of urinations and of Aconitum to decrease the number of stools produced by animals, an effect that was in the same direction as the activity of diazepam. Homeopathic medicines did not alter the general locomotion of mice in the OF, indicating that their effect was actually anxiolytic-like and not sedative, while buspirone significantly inhibited this parameter. 
Conclusions: Pharmacological effects of highly diluted/dynamized medicines on behavioural and emotional symptoms are clearly detectable also in experimental animals. Among the three tested remedies, in these model paradigms Gelsemium showed the highest activity, which was statistically significant as compared with pure solvent even in solutions diluted beyond the Avogadro constant. The effects of different medicines on the anxiety-like symptoms were qualitatively different and differed also from those of benzodiazepines and of serotonin partial agonists. These experiences raise some technical issues related to the animal models and to the possible translation to homeopathy in humans.

Acknowledgments: This work was supported by grants from Laboratoires Boiron s.r.l. (Milano, I) to Verona University - Department of Pathology and Diagnostics.

\section{Análise de dados com modelos comportamentais em camundongos submetidos a Gelsemium sepervirens e novos resultados para Ignatia amara e Aconitum napellus}

\section{RESUMO}

Objetivo: Nós investigamos os efeitos de três diferentes medicamentos homeopáticos em várias diluições/dinamizações em camundongos, usando modelos validados que exploram sintomas de ansiedade e de emocionalidade. Duas séries completas de investigações foram feitas de forma a estudar a atividade do Gelsemium sempervirens. Além disso, investigamos a Ignatia amara e o Aconitum napellus utilizando os mesmos modelos.

Métodos: Camundongos da linhagem CD1 foram randomizados em diferentes gaiolas (mínimo de 8 camundongos por tratamento em cada experimento) e as soluções foram codificadas de forma que todos os protocolos fossem executados completamente em cego. Os compostos indicados em várias diluições/dinamizações centesimais, a solução controle (solvente dinamizado) ou drogas de referência, como o Diazepam (1 mg/kg PV) ou a Buspirona (5 mg/kg PV) diluídos no mesmo solvente sucussionado foram administrados por via ip (0.3 ml/camundongo) por 9 dias. Uma série de mudanças no comportamento dos animais foi monitorada pelo teste de escolha claro/escuro (LD) e pelo campo aberto (OF). Duas séries com pequenas diferenças técnicas, explorando 14 experimentos independentes forem feitas com Gelsemium, cinco experimentos completos foram feitos com Ignatia e quatro com Aconitum.

Resultados: Em ambas as séries de experimentos feitos com Gelsemium, observaram-se efeitos de padrão ansiolítico em ambos os testes (OF e LD). Contudo, devido à grande variabilidade das respostas dos animais e possivelmente de algumas pequenas diferenças nos protocolos, esses efeitos alcançaram o limiar de significância estatística apenas para o campo aberto na primeira série e para o teste claro/escuro na segunda série. A análise cumulativa das duas séries demonstrou significância muito alta $(p \leq 0,0001)$ dos efeitos do Gelsemium 5CH, $7 \mathrm{CH}$ e $30 \mathrm{CH}$ para os parâmetros do campo aberto e do Gelsemium $5 \mathrm{CH}, 9 \mathrm{CH}$ e $30 \mathrm{CH}$ para os parâmetros do teste claro/escuro. No campo aberto, o efeito do Gelsemium foi particularmente diferente em comparação com as drogas de referência, sugerindo aumento no comportamento exploratório e redução na 
tigmotaxia e na neofobia, ao contrário do que se esperaria de um efeito ansiolítico clássico; no teste claro/escuro, os efeitos do Gelsemium foram similares aos do benzodiazepínico. A Ignatia mostrou efeitos estatisticamente significativos apenas no teste claro/escuro (pico na diluição 9CH), enquanto que o Aconitum apresentou efeito similar apenas em um experimento, onde o nível de ansiedade basal dos animais estava previamente elevado. Também observamos uma tendência de Ignatia em diminuir o número de marcas de urina e do Aconitum de diminuir o número de bolos fecais, ambos os efeitos são similares ao esperado para o Diazepam. Os medicamentos homeopáticos não alteraram a locomoção geral dos camundongos no campo aberto, indicando que seus efeitos foram realmente semelhantes ao ansiolítico e não simplesmente sedativos, enquanto que a Buspirona inibiu significativamente este parâmetro.

Conclusões: Os efeitos farmacológicos de medicamentos preparados em altas diluições/dinamizações sobre os sintomas comportamentais e emocionais são claramente detectáveis também em modelos animais. Entre os três medicamentos estudados, Gelsemium mostrou a maior atividade, que foi estatisticamente significativa quando comparado com o solvente, mesmo quando preparado acima do número de Avogadro. Os efeitos dos diferentes medicamentos sobre os sintomas semelhantes à ansiedade são qualitativamente diferentes e diferem também dos benzodiazepínicos e dos agonistas parciais da serotonina. Tais experiências permitem o desenvolvimento técnico de modelos animais e possíveis extrapolações para a homeopatia humana.

Agradecimentos: Esse trabalho recebeu suporte do Laboratório Boiron s.r.l. (Milão, I) para o departamento de Patologia e Diagnóstico da Universidade de Verona.

\section{(c) BY-NC-ND Licensed to GIRI}

Support: Laboratories Boiron s.r.l. (Milano, I)

Conflict of interest: authors declare there is no conflict of interest

Correspondence author: Paolo Bellavite, Department of Pathology and Diagnostics, University of Verona I, paolo.bellavite@univr.it

How to cite this article Bellavite P, Magnani P, Marzotto M, Cristofoletti M, Zanolin M, Conforti A. Mice behavioural models with pooled data analysis of Gelsemium studies and new findings about Ignatia and Aconitum. Int J High Dilution Res [online]. 2011 [cited YYYY Month dd]; 10(36): 198-200. Proceedings of the XXV GIRI Symposium and VIII CBFH; 2011 Sep 04-07; Foz do Iguaçu (Brazil). GIRI and ABFH; 2011; Available from: http://www.feg.unesp.br/ ojs/index.php/ijhdr/article/view/532/536 